\title{
Differential Impact of COVID-19 by Occupation: Survey Findings From Indian Punjab
}

\author{
Indervir Singh ${ }^{1}$ (D) ${ }^{\text {, }}$ Jagdeep Singh ${ }^{2}$, Ashapurna Baruah ${ }^{1}$ (D) \\ ${ }^{1}$ Department of Economics, Central University of Himachal Pradesh, Dharamshala, India, ${ }^{2}$ Guru Nanak College, Budhlada, India \\ Keywords: covid-19, lockdown, restricted occupations, differential impact \\ https://doi.org/10.46557/001c.27132
}

\section{Asian Economics Letters}

Vol. 2, Issue 4, 2021

This paper analyzes the differential impact of COVID-19 by occupation in Mansa, Punjab, India. Propensity score matching is used to analyze the difference in income recovery rates of permissible and restricted occupations based on restrictions in the initial period of the lockdown. Analysis of income of 55 randomly selected households shows that the restricted occupations lagged in their recovery rate after six months of lockdown.

\section{Introduction}

The outbreak of coronavirus disease in 2019 (COVID-19) has caused severe economic hardship across nations (Coibion et al., 2020; Fairlie et al., 2020; Gopinath, 2020). Strict lockdowns and the fear of COVID-19 caused intolerable suffering and privation to a large share of India's population (Centre for Equity Studies et al., 2020; Ray \& Subramanian, 2020). Studies have found that more than 80 percent of households earned no income from their main occupation between March 24 and May 5, 2020 (Afridi et al., 2020a, 2020b; Bertrand et al., 2020).

Although income and employment started recovering with easing of the lockdown after May 4, 2020, households continued to earn considerably less until mid-June 2020 compared to their pre-lockdown income (Singh et al., 2020). This period of a large drop in income and employment coincides with a 23.9 percent fall in gross domestic product (GDP) in the first quarter of India's financial year (April to June 2020). India's GDP showed signs of recovery (even though the growth rate was still -7.5 percent) in the second quarter (Government of India, 2020). While the trend indicates recovery, the aggregated data hide the nuances of the recovery process. Fear of COVID-19 and the policy of lockdown have a disproportionate effect across industries and occupations (Fairlie et al., 2020; Montenovo et al., 2020).

The disproportionate effects of COVID-19 lockdown by occupation in India remain relatively unexplored in the literature. We find no study that explores differential income recovery after easing of lockdown restrictions. This paper addresses this gap by analyzing the impact of lockdown restrictions on household income during the first six months of the COVID-19 outbreak (from March 22 to September 30, 2020) in Mansa, Punjab, India. The effect on household income is traced by analyzing the impact of lockdown restrictions on the main occupation of the household (the major source of income).

Occupations are divided into two categories based on whether they were permissible between March 22 and May 3 , 2020. The first category includes occupations that were either allowed during this period or where work from home (WFH) was possible ('permissible' occupations). The second category was neither allowed nor was WFH possible ('restricted' occupations). These occupations involve production of non-essential commodities and comprise mainly low-skill work.

This study compares the decline and recovery of household income for both occupational categories during the phases of COVID-19 restrictions using the propensity score matching (PSM) technique. The results show that households whose main occupation was in the restricted category during the initial phase of lockdown had a lower income recovery rate.

This paper proceeds as follows. Section II discusses data collection and methodology. Section III provides the results of the analysis and discusses the main findings. Finally, Section IV sets forth the conclusions.

\section{Data and Methodology}

This study is based on primary data. A survey of 55 households was conducted in the city of Mansa, Punjab, India. The data were collected using multi-stage random sampling. At the first stage, the city area was divided into two parts based on the railway line and the area to its north was chosen. At the second stage, this area was subdivided into 44 parts, of which 11 were randomly chosen. At the last stage, a total of 55 households - five from each of the selected parts - were randomly chosen for the survey. Among the surveyed households, 15 households had their main occupation under the permissible category. The remaining 40 households had their main occupation in the restricted cat- 
Table 1. Sample Mean and Standard Error of Control Variables

\begin{tabular}{lcccccc}
\multicolumn{1}{c}{ Variable } & & Mean & & & \multicolumn{2}{c}{ Standard Error } \\
& Restricted & Permissible & All & Restricted & Permissible & All \\
\hline $\begin{array}{l}\text { Pre-lockdown income (per person per } \\
\text { day) in rupees }\end{array}$ & 185.4 & 333.5 & 225.8 & 19.86 & 42.61 & 20.40 \\
$\begin{array}{l}\text { Number of working family members } \\
\begin{array}{l}\text { Years of schooling of main earning } \\
\text { members }\end{array}\end{array}$ & 1.4 & 1.6 & 1.5 & 0.10 & 0.19 & 0.09 \\
$\begin{array}{l}\text { SC (1if SC, } 0 \text { otherwise) } \\
\text { OBC (1 if OBC, } \text { O otherwise) }\end{array}$ & 9.5 & 13.8 & 10.7 & 0.70 & 0.59 & 0.59 \\
\hline
\end{tabular}

Notes: This table presents a summary (sample mean and standard errors of variables obtained from a primary survey.

egory.

The selected households were interviewed twice. The first round of interviews was conducted in June 2020. This round collected information on income in the pre-lockdown period and the four phases of the COVID-19 lockdown. These four phases of lockdown were as follows: Phase I from March 22 to April 19, 2020 (Punjab announced a curfew on March 22, 2020), Phase II from April 20 to May 3, 2020, Phase III from May 4 to May 17, 2020, and Phase IV from May 18 to June 17, 2020. The severity of lockdown was highest in Phase I and declined with each successive phase. The results of this round were published in Singh et al. (2020), which examines the income decline of the households and their survival strategies during this period. The same households were revisited for the second round in October 2020, when data on income were collected for July, August, and September 2020.

This study uses a t-test to check the significance of the difference between household income in various phases and household income during the pre-lockdown period for both categories. The test shows the period when the difference between income during pre-lockdown and the COVID-19 phase becomes insignificant for a category (McClave \& Sincich, 2018, Chapter 7). The coefficient of variation (CV) is calculated to examine deviation in household income. An increase in deviation represents unequal impact of the shock.

However, the t-test shows only change in income within a group and cannot be used to compare the restricted and permissible categories. The two groups differ significantly on household characteristics (Table 1). Even before lockdown, an average household in the restricted category earned 44 percent less, had 0.2 fewer working family members, and studied 3.3 years less than a permissible category household. Also, a restricted category household is more likely to belong to a Scheduled Caste (SC) or Other Backward Caste (OBC) household. Both these caste groups are more vulnerable than the others (Mitra et al., 2009). Hence, they may be more susceptible to an income shock.

Since the t-test does not control for these differences, we use PSM to examine the difference between the two cat- egories (see Dehejia \& Wahba, 2002 for a discussion on PSM and its application in non-experimental causal studies). The restricted category is considered a treated group for the analysis. It is assumed that the lockdown restrictions acted as a treatment for them.

Pre-lockdown income, number of working family members, years of schooling of main earning members, and belonging to an SC or OBC household are used as control variables (Table 1 provides mean and standard error for these covariates).

\section{Results and Discussion}

Households that received treatment were earning much lower income (Rs. 185 per day per person) compared to the control group (Rs. 334 per day per person) in the pre-lockdown period (Table 2). Household income dropped sharply during the lockdown. Income decline was much greater for the treated group. Both the treated and control groups showed a significant difference (based on t-test) in their income until August 2020 compared to their pre-lockdown income. Income in both groups reached the pre-lockdown level in September 2020 and the difference in income becomes insignificant.

The treated group also witnessed a sharp increase in CV of household income from 0.68 to 2.78 in Phase I, further increasing to 3.42 in Phase II. Although CV declined after Phase II, it remained higher in September 2020. In comparison, the control group had a minor increase in CV in Phase I, immediately declining in the next phase. This indicates the possibility that households in the treated group were more affected by the lockdown.

Average treatment effect on the treated group (ATT) shows a larger decline in income in Phase I (based on matched observations). The treated group was earning 10 percent of its pre-lockdown income compared to 41.1 percent for the control group. Phase III and Phase IV saw a sharp decline in the difference between the treated and control groups. However, the gap in the output variable again increased from July onwards. The treated and control groups showed a difference of 14.2 percentage points in September 2020. 
Table 2. Status of Work and Average per Day per Person Income of Sample Households (in Rs.) in Various Phases/Months

\begin{tabular}{|c|c|c|c|c|c|c|c|c|c|c|c|c|}
\hline \multirow{3}{*}{ Month/Phase } & \multicolumn{12}{|c|}{ Whether Work was 'Permissible' or 'Restricted' in Phase I and II } \\
\hline & \multicolumn{4}{|c|}{ Restricted Occupations (Treated) } & \multicolumn{4}{|c|}{ Permissible Occupations (Control) } & \multicolumn{4}{|c|}{ All } \\
\hline & Y & Difference & s & CV & Y & Difference & S & $\mathrm{CV}$ & Y & Difference & s & CV \\
\hline Pre-Lockdown & 185 & & & 0.68 & 334 & & & 0.49 & 226 & & & 0.67 \\
\hline Phase I & 32 & $\begin{array}{l}153^{* * *} \\
(16.1)^{c}\end{array}$ & 17.5 & 2.78 & 159 & $\begin{array}{l}175^{* * *} \\
(37.7)\end{array}$ & 47.7 & 0.65 & 67 & $\begin{array}{l}159^{* * *} \\
(15.5)\end{array}$ & 29.7 & 1.63 \\
\hline Phase II & 48 & $\begin{array}{l}138^{* * *} \\
(23.2)\end{array}$ & 25.8 & 3.42 & 272 & $\begin{array}{c}62^{*} \\
(30.8)\end{array}$ & 81.5 & 0.43 & 109 & $\begin{array}{l}117^{* * *} \\
(19.3)\end{array}$ & 48.2 & 1.67 \\
\hline Phase III & 61 & $\begin{array}{l}124^{* * *} \\
(19.8)\end{array}$ & 33.0 & 2.17 & 256 & $\begin{array}{c}78^{* *} \\
(30.8)\end{array}$ & 76.6 & 0.46 & 114 & $\begin{array}{l}112^{* * *} \\
(16.7)\end{array}$ & 50.6 & 1.35 \\
\hline Phase IV & 88 & $\begin{array}{l}98^{* * *} \\
(15.9)\end{array}$ & 47.4 & 1.20 & 232 & $\begin{array}{l}102^{* * *} \\
(23.3)\end{array}$ & 69.5 & 0.54 & 127 & $\begin{array}{l}99^{* * *} \\
(13.1)\end{array}$ & 56.3 & 1.00 \\
\hline July & 160 & $\begin{array}{c}25^{* * *} \\
(7.3)\end{array}$ & 86.5 & 0.81 & 296 & $\begin{array}{c}38^{* * *} \\
(11)\end{array}$ & 88.6 & 0.49 & 197 & $\begin{array}{c}29^{* * *} \\
(6.1)\end{array}$ & 87.3 & 0.74 \\
\hline August & 169 & $\begin{array}{l}17^{*} \\
(8.8)\end{array}$ & 91.0 & 0.85 & 310 & $\begin{array}{l}24^{* *} \\
(9.9)\end{array}$ & 92.8 & 0.50 & 207 & $\begin{array}{l}19^{* * *} \\
(6.9)\end{array}$ & 91.8 & 0.77 \\
\hline September & 175 & $\begin{array}{c}10 \\
(8.9)\end{array}$ & 94.6 & 0.82 & 331 & $\begin{array}{c}3 \\
(12.7)\end{array}$ & 99.1 & 0.52 & 218 & $\begin{array}{c}8 \\
(7.3)\end{array}$ & 96.4 & 0.76 \\
\hline
\end{tabular}

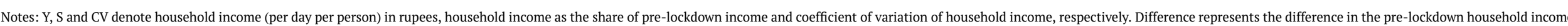

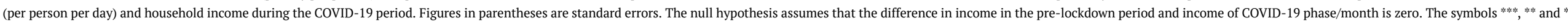
denote levels of statistical significance at $1 \%, 5 \%$, and $10 \%$, respectively. The data was collected through a primary survey. 


\begin{tabular}{|c|c|c|c|c|c|}
\hline \multirow[t]{2}{*}{ Month/Phase } & \multicolumn{5}{|c|}{ ATT (matched) } \\
\hline & Treated & Controls & Difference & S.E. & t-statistics \\
\hline Phase I & 10 & 41.1 & -31.1 & 18.8 & -1.66 \\
\hline Phase II & 16.4 & 53.9 & -37.5 & 29.9 & -1.25 \\
\hline Phase III & 28 & 51.2 & -23.1 & 25.4 & -0.91 \\
\hline Phase IV & 46.3 & 46 & 0.3 & 16.5 & 0.02 \\
\hline July & 85.7 & 104.2 & -18.5 & 7.8 & -2.37 \\
\hline August & 88.5 & 102.7 & -14.3 & 10.5 & -1.35 \\
\hline September & 92.9 & 107.1 & -14.2 & 6.9 & -2.05 \\
\hline \multicolumn{6}{|c|}{ Unmatched } \\
\hline Phase I & 10 & 50 & -40 & 7.7 & -5.22 \\
\hline Phase II & 16.4 & 85.6 & -69.2 & 11.4 & -6.06 \\
\hline Phase III & 28 & 80 & -52 & 10.6 & -4.89 \\
\hline Phase IV & 46.3 & 70.3 & -24 & 7.5 & -3.2 \\
\hline July & 85.7 & 89.8 & -4.1 & 6.1 & -0.67 \\
\hline August & 88.5 & 92.6 & -4.2 & 7.3 & -0.57 \\
\hline September & 92.9 & 99.5 & -6.6 & 7.3 & -0.9 \\
\hline
\end{tabular}

Notes: ATT measures the average effect of treatment (COVID-19 restrictions) on households that received the treatment. The method matches the treated and control groups based on control variables. Households with similar characteristics (matched households) are used to compare the income recovery in the two categories. Unmatched represents households that differ in their basic characteristics. The data was collected through a Primary survey.

Overall, the treated group seems to continue doing worse than the control group after controlling for other variables. This suggests that the lockdown effect on households whose main occupation was in the restricted category may persist. Fear of COVID-19 may also be playing a role, as some occupations in the restricted category require close contact between customers and the service provider.

Although the present study is based on a small sample, the possibility of a similar difference in recovery rate cannot be ignored for the overall population. Given the larger disproportionate impact of the pandemic on restricted occupations, many of them may need assistance to recover. The government should focus on estimating the differential outcomes of COVID-19 and take appropriate measures to induce faster recovery. The government may also consider expanding the Mahatma Gandhi National Rural Employment Guarantee Scheme (MGNREGS) and extending its benefits to urban areas.

\section{Conclusion}

This paper analyzes the impact of COVID-19 on household income by dividing occupations into restricted and permissible categories based on lockdown restrictions in the first two phases of the pandemic restrictions. The results of PSM show that households in the restricted category witnessed slower income recovery than those in the permissible category. These findings suggest that the initial lockdown restrictions may continue to cause differential outcomes for restricted occupations even after restrictions are lifted.

\section{Acknowledgment}

We are extremely grateful to the anonymous reviewer and the editor, Dr Susan Sharma. Their comments and suggestions greatly improved the quality of our paper.

Submitted: February 07, 2021 AEDT, Accepted: April 27, 2021 AEDT 


\section{REFERENCES}

Afridi, F., Dhillon, A., \& Roy, S. (2020a). How has Covid-19 crisis affected the urban poor? Findings from a phone survey- $I$. Ideas for India. https://www.ideasfori ndia.in/topics/poverty-inequality/how-has-covid-1 9-crisis-affected-the-urban-poor-findings-from-a-ph one-survey.html

Afridi, F., Dhillon, A., \& Roy, S. (2020b). How has Covid-19 crisis affected urban poor? Findings from a phone survey - II. Ideas for India. https://www.ideasfor india.in/topics/poverty-inequality/how-has-covid-1 9-crisis-affected-urban-poor-findings-from-a-phonesurvey-ii.html

Bertrand, M., Krishnan, K., \& Schofield, H. (2020). How are Indian Households coping under the COVID-19 lockdown? 8 key findings. University of Chicago, Becker Friedman Institute for Economics. https://www.chica gobooth.edu/research/rustandy/blog/2020/how-are-i ndian-households-coping-under-the-covid19-lockdo $\underline{w n}$

Centre for Equity Studies, Delhi Research Group, \& Karwan-e-Mohabbat. (2020). Labouring Lives: Hunger, Precarity and Despair amid Lockdown. Centre for Equity Studies. http://centreforequitystudies.org/wpcontent/uploads/2020/06/Labouring-Lives-_Final-Rep ort.pdf

Coibion, O., Gorodnichenko, Y., \& Weber, M. (2020). The Cost of the Covid-19 Crisis: Lockdowns, Macroeconomic Expectations, and Consumer Spending. Working Paper No. 27141; NBER. https://doi.org/10.3386/w27141

Dehejia, R. H., \& Wahba, S. (2002). Propensity scorematching methods for nonexperimental causal studies. Review of Economics and Statistics, 84(1), 151-161. https://doi.org/10.1162/0034653023173319 $\underline{82}$
Fairlie, R. W., Couch, K., \& Xu, H. (2020). The Impacts of COVID-19 on Minority Unemployment: First Evidence from April 2020 CPS Microdata. Working Paper No. 27246; NBER. https://doi.org/10.3386/w27246

Gopinath, G. (2020). The Great Lockdown: Worst Economic Downturn Since the Great Depression. IMF Blog. https://blogs.imf.org/2020/04/14/the-great-lock down-worst-economic-downturn-since-the-great-de pression/

Government of India. (2020). Estimates of Gross Domestic Product for the Second Quarter (JulySeptember) of 2020-21. Ministry of Statistics \& Programme Implementation. https://pib.gov.in/Pressr eleaseshare.aspx?PRID $=1676486$

McClave, J. T., \& Sincich, T. (2018). A First Course in Statistics (12th ed.). Pearson Education.

Mitra, A., Kumar, R., \& Kumar, S. (2009). Social and Economic Inequalities: Contemporary Significance of Caste in India. Economic and Political Weekly, 44(50), $55-63$.

Montenovo, L., Jiang, X., Rojas, F. L., Schmutte, I. M., Simon, K. I., Weinberg, B. A., \& Wing, C. (2020). Determinants of Disparities in Covid-19 Job Losses. Working Paper No. 27132; NBER. https://doi.org/10.3 $\underline{386 / w 27132}$

Ray, D., \& Subramanian, S. (2020). India's Lockdown: An Interim Report. Working Paper No. 27282; NBER. http s://doi.org/10.3386/w27282

Singh, I., Singh, J., \& Baruah, A. (2020). Income and Employment Changes Under COVID-19 Lockdown: A Study of Urban Punjab. Millennial Asia, 11(3), 391-412. https://doi.org/10.1177/0976399620957630 